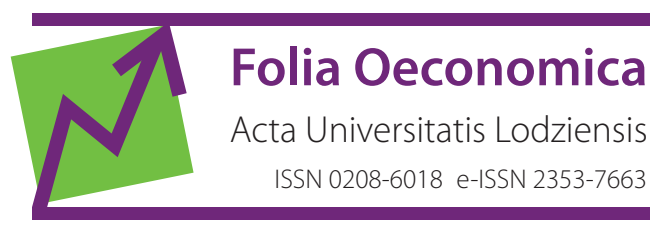

www.czasopisma.uni.lodz.pl/foe/

$1(340) 2019$

DOI: http://dx.doi.org/10.18778/0208-6018.340.09

\title{
Ewa Baran
}

Uniwersytet Rzeszowski, Wydział Ekonomii, Katedra Polityki Gospodarczej, ebaran5@wp.pl

\section{Bogumiła Grzebyk}

Uniwersytet Rzeszowski, Wydział Ekonomii, Katedra Polityki Gospodarczej, bog.grzebyk@interia.pl

\section{Zasoby mieszkaniowe ośrodków miejskich Podkarpacia czynnikiem konkurencyjności regionu}

\begin{abstract}
Streszczenie: Analiza zebranego materiału badawczego dowiodła, że zasoby mieszkaniowe ośrodków miejskich Podkarpacia mogą stanowić ważny czynnik rozwoju potencjału demograficznego, decydujący o procesach migracji, zwłaszcza wśród ludzi młodych, a to z kolei przekłada się na wzrost konkurencyjności regionu w skali kraju i UE. Stolica regionu - Rzeszów - stanowi przykład dużego miasta, do którego od kilku lat migruje ludność z terenów wiejskich województwa ze względu na lepsze warunki życia i pracy. Przy pojawieniu się w kraju miast wyludniających się, takich jak Łódź czy Poznań - Rzeszów, obok Warszawy, stanowi magnes przyciągający nowych mieszkańców. Potwierdzeniem tego jest rekordowa sprzedaż nowych mieszkań na rynku pierwotnym i wzrastająca liczba nowych mieszkań pod wynajem w ostatnich kilku latach. Zaznaczyć należy, że na taki stan rzeczy wpływ miały zmiany czynników ekonomicznych, głównie wzrost wynagrodzeń, spadek bezrobocia oraz silniejszy wzrost PKB. Wskaźniki demograficzne, tj. przyrost naturalny, dodatnie saldo migracji i liczba nowo zawieranych małżeństw to dla części miast dodatkowe czynniki, które wpłynęły pozytywnie na popytową stronę rynku mieszkaniowego. Niestety, występujące zjawisko depopulacji oraz starzenia się społeczności w wielu ośrodkach miejskich Podkarpacia nie jest dobrym prognostykiem na przyszłość.
\end{abstract}

Słowa kluczowe: zasoby mieszkaniowe, depopulacja, konkurencyjność

JEL: R31 


\section{Wprowadzenie}

W każdym kraju miasta stanowią zogniskowane ośrodki życia gospodarczego, społecznego, kulturalnego i politycznego, są głównym miejscem skupienia ludności i w nich powstaje zasadnicza część efektów gospodarowania (Adamowicz, Janulewicz, 2016: 69).

Polską przestrzeń charakteryzuje gęsta i policentryczna sieć miast. Odgrywa ona istotną rolę w generowaniu wzrostu gospodarczego, przyciąganiu inwestycji, rozwoju przedsiębiorczości. Jednocześnie polskie ośrodki miejskie są w znacznym stopniu zróżnicowane wewnętrznie i zewnętrznie. W dokumencie Krajowa Polityka Miejska 2023 za cel strategiczny przyjęto wzmocnienie zdolności miast i obszarów zurbanizowanych do kreowania zrównoważonego rozwoju i tworzenia miejsc pracy oraz poprawy jakości życia mieszkańców (Korenik, 2015: 49).

Miasto ogólnie rozumiane jest jako swego rodzaju system składający się z określonych elementów, między którymi zachodzą określone relacje (np. materialne, energetyczne czy decyzyjne) (Gorzelak, 2008: 89).

Rozwój miasta jest procesem dokonującym się na skutek działania wielu czynników o charakterze ekonomicznym, społecznym, historycznym oraz przestrzennym. Ich znaczenie nie jest równoważne, a ich wpływ na rozwój lokalny jest zależny przede wszystkim od specyfiki danego miasta (Sobol, 2010: 215). Inaczej mówiąc, jest to proces zachodzący w wyniku wykorzystywania miejscowych zasobów, służący zaspokajaniu potrzeb społeczności lokalnej. Przekształcenia dokonujące się w strukturze przestrzennej i funkcjonalnej miasta, następujące w sposób ewolucyjny i nierzadko trudno dostrzegalny, są cechą rozwoju społeczno-gospodarczego (Brol, 2001: 14-15).

Komisja Europejska w dokumencie Miasta przyszłości. Wyzwania, wizje, perspektywy przypisuje miastom kluczową rolę i wskazuje model przyszłego rozwoju terytorialnego miast w Europie, który powinien:

1) bazować na zrównoważonym wzroście gospodarczym i terytorialnej organizacji działań, przy założeniu policentrycznej struktury miejskiej;

2) opierać się na silnych regionach metropolitalnych i innych obszarach miejskich, które mogą zapewniać dobry dostęp do usług ogólnego zainteresowania gospodarczego;

3) charakteryzować się zwartą zabudową oraz ograniczeniem niekontrolowanego rozlewania się miast;

4) charakteryzować się wysokim poziomem ochrony i jakości środowiska w miastach i wokół miast.

Wspólna wizja europejskiego miasta przyszłości zakłada, że będą to:

1) miejsca zaawansowanego postępu społecznego, $z$ wysokim poziomem spójności społecznej, społecznie zrównoważonym mieszkalnictwem, usługami socjalnymi i zdrowotnymi oraz ogólnodostępnym szkolnictwem; 
2) platformy procesu demokratycznego, dialogu kulturowego i różnorodności kulturowej;

3) miejsca rewitalizacji przyrodniczej, ekologicznej i środowiskowej;

4) miejsca atrakcji i lokomotywy wzrostu gospodarczego (Miasta przyszłości..., 2011: 2-3).

Jednym z ważniejszych wyzwań globalnej gospodarki staje się wzrastająca ranga kreatywności jako czynnika rozwoju społeczno-gospodarczego jednostek przestrzennych, organizacji przedsiębiorstw. W gospodarce kreatywnej najbardziej pożądanym czynnikiem wytwórczym jest człowiek, który wykazuje tendencje do koncentracji w ściśle określonych przestrzeniach (miastach), spełniających określone kryteria w odniesieniu do pracy i zamieszkania (Korenik, 2015: 37-38). Z tego punktu widzenia atrakcyjność miast staje się walorem regionu.

Rozwój miast łączy się w istotny sposób z rozwojem lokalnym i regionalnym, co w warunkach współczesnych przekłada się na zjawisko konkurencyjności, sięgające nawet poziomu międzynarodowego (Brol, 2001: 242). Ponadto mieszkaniowy majątek trwały jest podstawowym ogniwem infrastruktury osadniczej, wzmacniającym aktywność ludzką w wielu aspektach. Stanowi istotny składnik dorobku ludzkiego i jest inwestycją w rozwój cywilizacji i kultury. Rola państwa w tworzeniu regulacji prawnych, kształtowaniu budownictwa mieszkaniowego oraz stymulowaniu tempa jego rozwoju rośnie od wielu lat i związana jest z polityką gospodarczą (Cesarski, 1998).

Wśród obszarów strategicznych wyzwań sformułowanych w krajowej Strategii Rozwoju Regionalnego 2010-2020, na które polityka regionalna - wspierająca konkurencyjność regionów i zapewniająca spójność terytorialną kraju - musi odpowiedzieć, wymienia się na pierwszym miejscu lepsze wykorzystanie potencjałów najważniejszych obszarów miejskich do kreowania wzrostu i zatrudnienia oraz stymulowania rozwoju pozostałych obszarów (Krajowa Strategia Rozwoju Regionalnego 2010-2020, 2010: 24).

Na tle kraju Podkarpacie cechuje się najniższym odsetkiem ludności miejskiej, niższą gęstością miast wyrażoną ich liczbą na tysiąc $\mathrm{km}^{2}$ oraz ponadprzeciętnym udziałem małych miast (do 20 tys. mieszkańców) (Męczyński, Konecka-Szydłowska, Gadziński, 2010: 20-21). Przyjmując kryterium, w myśl którego miasta liczące ponad 100 tys. mieszkańców to miasta duże $e^{1}$, spośród 51 miast Podkarpacia tylko Rzeszów - stolica województwa - znajduje się w tej grupie.

Celem niniejszego opracowania jest ocena potencjału zasobów mieszkaniowych ośrodków miejskich Podkarpacia w świetle przemian demograficznych stanowiących ważny element rozwoju społeczno-gospodarczego regionu. Przedmiot badań stanowi 21 miast powiatowych województwa podkarpackiego, będących lokalnymi ośrodkami rozwoju regionu. Podkarpacie cechuje niskie zaawansowanie

1 W 2015 roku w Polsce było 39 dużych miast - zob. Adamowicz, Janulewicz, 2016: 68-85. 
procesu urbanizacji $(40,4 \% \mathrm{w} 2005$ roku, wzrosło do 41,3\% w 2015 roku) w porównaniu do przeciętnej sytuacji w kraju $(60,3 \%$ w 2015 roku). Z wyjątkiem stolicy regionu - Rzeszowa - miasta te należą do kategorii małych i średnich, stąd pojawia się kwestia czynników decydujących o procesach migracji, wśród których warunki mieszkaniowe wydają się istotne dla rozwoju ich potencjału demograficznego. W badanej grupie miast powiatowych Podkarpacia można wyróżnić 4 miasta posiadające status powiatu grodzkiego (byłe stolice w poprzednim układzie 49 województw), w tym ośrodek regionalny miasto Rzeszów. Według danych GUS z 2015 roku miastami średnimi są: Mielec, Przemyśl i Stalowa Wola (50-100 tys.) oraz Dębica, Jarosław, Jasło, Krosno, Sanok i Tarnobrzeg (20-50 tys.). Pozostałe² - stanowiące ponad połowę miast Podkarpacia - to małe ośrodki miejskie liczące do 20 tys. mieszkańców. Do oceny stanu zasobów mieszkaniowych i sytuacji demograficznej wykorzystano metodę wskaźnikową z uwzględnieniem danych dostępnych w BDL GUS za lata 2005-2015.

\section{Zmiany potencjału demograficznego podkarpackich miast}

W województwie podkarpackim odnotowuje się ogólnie korzystniejsze trendy demograficzne w porównaniu do przeciętnych warunków w Polsce (tab. 1).

Tabela 1. Potencjał demograficzny miast Podkarpacia na tle kraju (tys. osób)

\begin{tabular}{|l|r|r|r|r|}
\hline \multirow{2}{*}{ Jednostka } & \multicolumn{3}{|c|}{ Lata } & \multirow{2}{*}{ Dynamika 2005 = 100 } \\
\cline { 2 - 5 } & \multicolumn{1}{|c|}{$\mathbf{2 0 0 5}$} & \multicolumn{1}{|c|}{$\mathbf{2 0 1 0}$} & \multicolumn{1}{c|}{$\mathbf{2 0 1 5}$} & \\
\hline Polska & 38157055 & 38529866 & 38437239 & 100,7 \\
\hline Woj. podkarpackie & 2098263 & 2127948 & 2127657 & 101,4 \\
\hline Miasta powiatowe: & 748040 & 765454 & 757587 & 101,3 \\
\hline Krosno & 47817 & 47516 & 46775 & 97,8 \\
\hline Przemyśl & 66909 & 65096 & 62720 & 93,7 \\
\hline Rzeszów & 158539 & 179199 & 185896 & 117,3 \\
\hline Tarnobrzeg & 50115 & 48886 & 47816 & 95,4 \\
\hline Pozostałe miasta powiatowe: & 424660 & 424757 & 414380 & 97,6 \\
\hline Ustrzyki Dolne & 9521 & 9665 & 9335 & 98,0 \\
\hline Brzozów & 7745 & 7697 & 7509 & 97,0 \\
\hline Jasło & 37811 & 37148 & 36001 & 95,2 \\
\hline Sanok & 39552 & 39569 & 38486 & 97,3 \\
\hline Lesko & 5875 & 5777 & 5590 & 95,1 \\
\hline
\end{tabular}

2 Pozostałe 11 miast zaliczanych do małych ośrodków miejskich to: Ustrzyki Dolne, Brzozów, Lesko, Lubaczów, Przeworsk, Kolbuszowa, Łańcut, Ropczyce, Strzyżów, Leżajsk i Nisko. 


\begin{tabular}{|l|r|r|r|r|}
\hline \multirow{2}{*}{\multicolumn{1}{c|}{ Jednostka }} & \multicolumn{3}{|c|}{ Lata } & \multirow{2}{*}{ Dynamika 2005 = 100 } \\
\cline { 2 - 4 } & $\mathbf{2 0 0 5}$ & $\mathbf{2 0 1 0}$ & $\mathbf{2 0 1 5}$ & \\
\hline Jarosław & 40677 & 39947 & 38360 & 94,3 \\
\hline Lubaczów & 12387 & 12586 & 12304 & 99,3 \\
\hline Przeworsk & 15746 & 15971 & 15585 & 99,0 \\
\hline Kolbuszowa & 9179 & 9441 & 9236 & 100,6 \\
\hline Lańcut & 18076 & 18183 & 17830 & 98,6 \\
\hline Ropczyce & 15070 & 15545 & 15717 & 104,3 \\
\hline Strzyżów & 8699 & 8918 & 8925 & 102,6 \\
\hline Dębica & 47054 & 47243 & 46389 & 98,6 \\
\hline Leżajsk & 14297 & 14538 & 14122 & 98,8 \\
\hline Mielec & 61241 & 61587 & 60644 & 99,0 \\
\hline Nisko & 15633 & 15625 & 15423 & 98,7 \\
\hline Stalowa Wola & 66097 & 65317 & 62924 & 95,2 \\
\hline
\end{tabular}

Źródło: dane BDL GUS

Uwzględniając zmiany liczby ludności między 2005 i 2015 rokiem, zauważono w kraju niewielki wzrost ludności ogółem (o $0,73 \%$ ) i jednoczesny ubytek ludności miast $(-1,1 \%)$, na Podkarpaciu wzrosła zaś ogólna liczba ludności - w tym w miastach (odpowiednio o 1,34 i 3,64\%). Pozytywne zmiany wystąpiły zasadniczo między 2005 i 2010 rokiem, gdyż w kolejnych latach, tj. 2010-2015, odnotowano ubytek mieszkańców, natężony bardziej w ośrodkach miejskich: w krajowych o $1,1 \%$, a w podkarpackich miastach o $0,1 \%$. Korzystne zmiany ludnościowe wystąpiły głównie na obszarach wiejskich i w małych miastach, gdyż badanie zmian stanu ludności z wyróżnieniem miast powiatowych regionu ujawniło zmniejszenie się zasobów ludności w latach 2010-2015 z nielicznymi tylko wyjątkami, tj. miastami: Kolbuszowa, Ropczyce, Rzeszów i Strzyżów. Zaznaczyć należy, że w przypadku stolicy województwa - Rzeszowa - jest to także wynikiem powiększania jego terytorium od 2006 roku (z 54 do $117 \mathrm{~km}^{2}$ ) i włączenia w jego granice przyległych miejscowości, w związku z czym wzrosła liczba mieszkańców (z 158,5 tys. do 185,8 tys. osób) w całym badanym okresie o $17,3 \%$, w tym o $3,7 \%$ w latach 2010-2015.

Od 2005 do 2015 roku zjawisko depopulacji miast powiatowych Podkarpacia wystąpiło najmocniej w takich miastach, jak: Przemyśl (-6,3\%), Jarosław $(-5,7 \%)$, Lesko $(-4,9 \%)$, Jasło i Stalowa Wola $(-4,8 \%)$, Tarnobrzeg $(-4,6 \%)$ oraz Brzozów (-3,1\%), Sanok (-2,7\%), i Krosno (-2,2\%). Podkreślić należy, że miało ono charakter systematycznego ubytku w kolejnych latach od 2010 roku, a ten znaczny spadek liczby mieszkańców dotyczył trzech miast, które straciły status siedzib dawnych województw regionu. Wiąże się to $z$ faktem położenia dawnych województw przemyskiego i krośnieńskiego w obszarze peryferyjnym z uwagi na bliskość granicy województwa i kraju. Zjawisko to potwierdza wskaźnik zmian liczby ludności w przeliczeniu na tysiąc mieszkańców zaprezentowany na rysunku 1. 


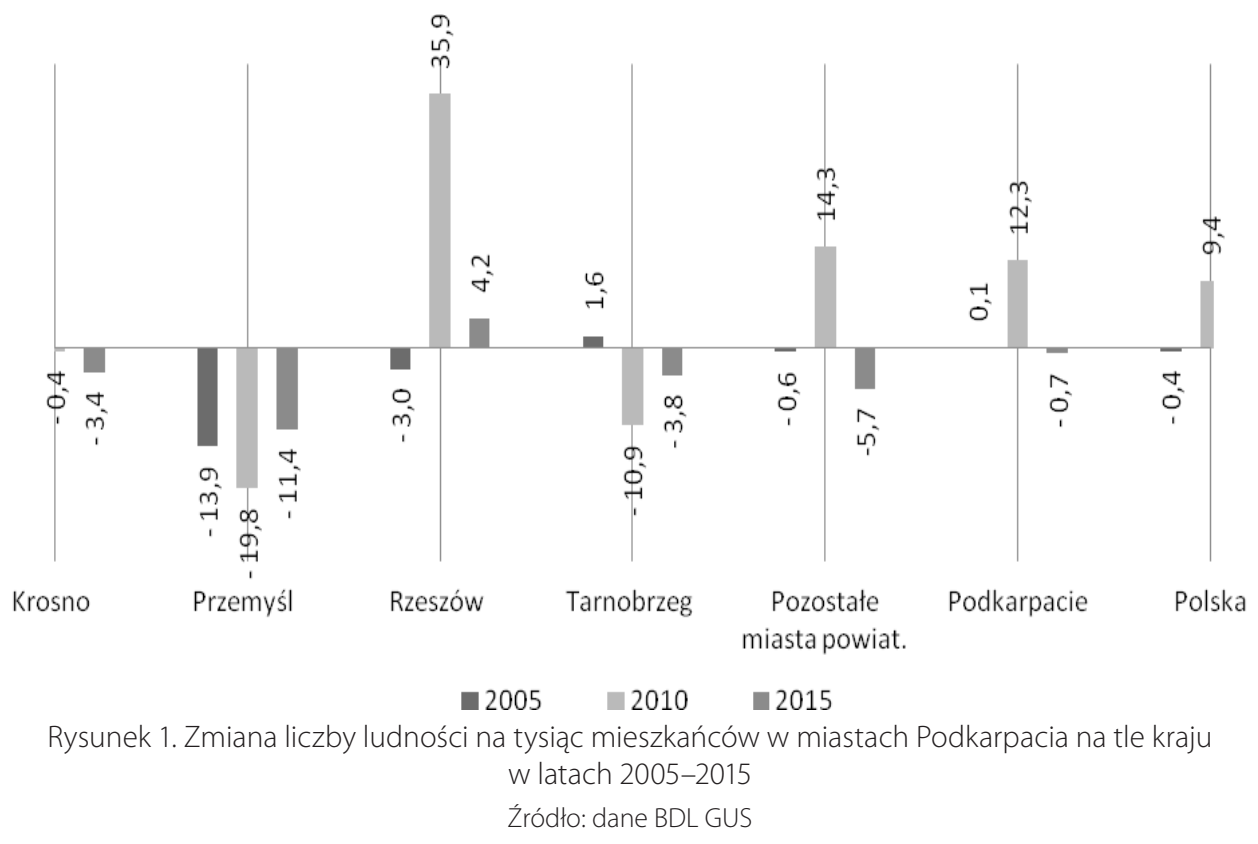

Zauważone zmiany potwierdzają założenia Koncepcji Przestrzennego Zagospodarowania Kraju do 2030 (2011: 38) wskazujące na koncentrację ludności zarówno w dużych ośrodkach miejskich, jak i w ich obszarach funkcjonalnych, gdzie napłynie ludność z obszarów wiejskich. W odniesieniu do analizowanego regionu wzrastająca liczba ludności w podregionie rzeszowskim (o blisko 12\%), przy znaczącym ubytku w podregionach: krośnieńskim (o 3,2\%), przemyskim (o 5,2\%) i tarnobrzeskim (o 2,9\%), może być potwierdzeniem tego zjawiska.

Sytuacja demograficzna jest efektem oddziaływania wielu czynników, wśród których jednym z najważniejszych jest niekorzystna sytuacja na lokalnych rynkach pracy, co skutkuje migracją, zwłaszcza ludzi młodych, do innych ośrodków miejskich. Wpływa to dodatkowo na obniżenie salda przyrostu naturalnego (tab. 2).

W badanych latach stwierdzono ujemne saldo migracji w miastach powiatowych regionu ${ }^{3}$ poza Rzeszowem, gdzie kolejno od 2010 roku występowały wyższe wartości wskaźnika. Obszar migracji do stolicy regionu to głównie tereny wiejskie oraz mniejsze miasta.

Warty dodania jest również fakt, że na Podkarpaciu występowała ogólnie mniejsza skala migracji zagranicznych niż średnio w kraju. Bardziej dotknięte tym były jednak miasta powiatowe regionu, gdzie poza pojedynczymi przypadkami dominowała emigracja. Nasilona emigracja od 2010 roku występowała wahadło-

3 W 2005 roku wyjątkiem była Kolbuszowa $(0,1)$, a w 2010 roku Ropczyce $(0,6)$. 
wo w kolejnych latach głównie w miastach: Ustrzyki Dolne (od -6,0 w 2010 roku, przez -11,8; -8,0; -13,5, do -2,6 w 2014 roku), Brzozów, Dębica, Jarosław, Kolbuszowa, Lesko, Leżajsk i Stalowa Wola ${ }^{4}$.

Tabela 2. Wskaźniki demograficzne miast Podkarpacia na tle kraju w latach 2005-2015

\begin{tabular}{|l|r|r|r|r|r|r|}
\hline \multirow{2}{*}{ Jednostka } & \multicolumn{3}{|c|}{$\begin{array}{c}\text { Saldo migracji na tysiąc } \\
\text { osób }\end{array}$} & \multicolumn{3}{c|}{$\begin{array}{c}\text { Przyrost naturalny/tysiąc } \\
\text { osób }\end{array}$} \\
\cline { 2 - 7 } & $\mathbf{2 0 0 5}$ & $\mathbf{2 0 1 0}$ & $\mathbf{2 0 1 4} *$ & $\mathbf{2 0 0 5}$ & $\mathbf{2 0 1 0}$ & $\mathbf{2 0 1 5}$ \\
\hline Polska & $-0,3$ & $-0,1$ & $-0,4$ & $-0,1$ & 0,9 & $-0,7$ \\
\hline Woj. podkarpackie & $-1,1$ & $-0,9$ & $-1,1$ & 1,1 & 1,7 & 0,1 \\
\hline Miasta powiatowe: & $-4,5$ & $-3,0$ & $-5,5$ & 0,5 & 1,6 & $-1,1$ \\
\hline Krosno & $-5,3$ & $-4,0$ & $-3,3$ & $-0,6$ & $-0,9$ & $-3,7$ \\
\hline Przemyśl & $-2,0$ & 1,0 & 2,3 & 1,9 & 2,9 & 2,2 \\
\hline Rzeszów & $-2,8$ & $-5,5$ & $-3,4$ & 1,7 & 1,3 & $-0,5$ \\
\hline Tarnobrzeg & $-4,5$ & $-4,3$ & $-4,8$ & 1,7 & 2,6 & 0,2 \\
\hline Pozostałe miasta powiatowe
\end{tabular}

* Podano dane dla 2014 roku z uwagi na brak informacji dla 2015 roku.

Źródło: dane BDL GUS

Przy ogólnie dodatnim przyroście naturalnym dla województwa podkarpackiego wskaźniki dla miast powiatowych do 2010 roku wykazywały generalnie wartości dodatnie. Jednak w kolejnych latach ujawniało się zróżnicowanie wskaźnika, a w badanych miastach i wybranych latach analizy wystąpił ubytek naturalny. Przy najbardziej niekorzystnej sytuacji dla Przemyśla (ubytek naturalny wystąpił we wszystkich latach) w 2011 roku ujemne saldo zanotowano w Sanoku $(-0,8)$, w 2012 w Jaśle $(-0,6)$, Lesku $(-1,9)$, Łańcucie $(-0,9)$ i Nisku $(-1,2)$, w 2013 roku w Jaśle $(-0,2)$, Jarosławiu $(-0,1)$, Przeworsku $(-0,5)$ i Tarnobrzegu $(-1,1)$. W 2014 roku takich miast było 9 - z najniższą wartością dla Brzozowa $(-3,3)$, natomiast w 2015 roku było to 11 miast - z najniższą wartością dla Przemyśla (tabela 2). Najwyższy dodatni przyrost naturalny wystąpił w 2010 roku w Lesku (5,7), a w kolejnych dwóch latach w Ropczycach (5,0 oraz 6,7), w 2013 i 2014 roku w Kolbuszowej $(5,5$ i 3,9), a w 2015 roku ponownie w Ropczycach $(2,9)$. Efektem negatywnych zjawisk demograficznych jest starzenie się społeczeństwa, co najwydatniej przedstawia relacja osób w wieku poprodukcyjnym na 100 osób w wieku przedprodukcyjnym przedstawiona na rysunku 2.

4 Odpowiednio dla miast: Brzozów: $-5,3 ;-6,9 ;-8,4 ;-2,2 ;-10,3$ i $-0,3$; Dębica: $-6,3 ;-3,7 ;-4,5$; $-7,5$ i $-7,0$; Jarosław: $-7,1 ;-6,0 ;-5,4 ;-5,9 ;-7,6$; Kolbuszowa: $-5,5 ;-9,5 ;-6,4 ;-7,4$ i $-9,0$; Lesko: $-0,5 ;-5,0 ;-7,5 ;-10,8$ i $-3,0$; Leżajsk: $-4,4 ;-4,8 ;-3,7 ;-8,9$ i $-7,1$; Stalowa Wola: $-9,1$; $-9,5 ;-9,6 ;-8,1 ;-7,9$. Nieco mniejsze wahania, ale wysokie ujemne wskaźniki, wystąpiły także w Jaśle (wartości z przedziału od -7,5 do -4,5), Sanoku (od -6,9 do -4,6), Lubaczowie (od $-5,0$ do $-2,2$ ) czy Przeworsku (od $-7,8$ do $-3,3$ ). 


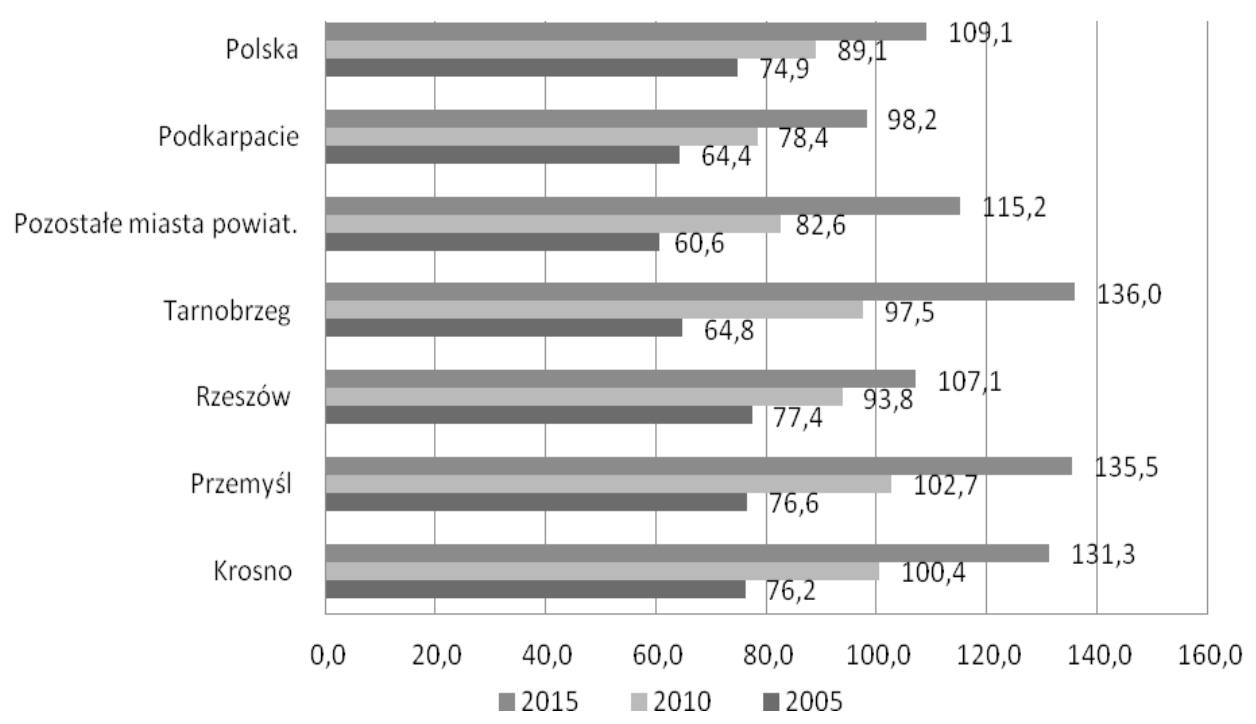

Rysunek 2. Liczba osób w wieku poprodukcyjnym na 100 osób w wieku przedprodukcyjnym

Źródło: obliczenia własne na podstawie danych BDL GUS

Koncentracja młodszych grup wiekowych ludności w miejskich ośrodkach regionu wiąże się z poszukiwaniem lepszych warunków życia i możliwości rozwoju osobistego dzięki kształceniu na poziomie wyższym, a następnie otrzymaniu korzystnych ofert pracy. W takich zbiorowościach częściej podejmowane są decyzje związane z usamodzielnieniem i dotyczące zawierania związków małżeńskich oraz niezależnością mieszkaniową, co wpływa na popyt na mieszkania. Jak pokazują dane statystyczne, Podkarpacie wyróżnia się na tle kraju wyższymi wskaźnikami liczby zawieranych małżeństw na tysiąc osób: w 2005 roku średnio o 3\%, z rosnącą przewagą w kolejnych latach od 2010 do 2015 roku, co dotyczyło większości powiatowych miast regionus.

Dlatego też szczególną uwagę należy zwrócić na mieszkalnictwo, które jest dziedziną silnie związaną z wieloma aspektami życia społecznego, ale także gospodarczego. Ma wpływ na sferę produkcji, handlu i usług. Kreuje popyt na materiały i usługi związane z budową, modernizacją, remontem czy wyposażeniem mieszkań. Ponadto jest silnie powiązane z rozwojem infrastruktury, ponieważ budowa mieszkań wymusza konieczność uzbrojenia terenów oraz ich zagospodarowania (Cesarski, 1998).

5 Przykładowo: w 2005 roku średnia krajowa wynosiła 5,4, dla regionu 5,6, a najwyższy wskaźnik był w Przeworsku 7,5 oraz Leżajsku 6,8. Odpowiednio w 2010 roku w kraju 5,9; w regionie 6,2, a najwyższy wskaźnik w Ropczycach 8,5, Kolbuszowej 8,1 i Brzozowie 8,0. W 2015 roku wyglądało to następująco: w kraju 4,9; w regionie 5,1, a najwyższy wskaźnik w Ustrzykach Dolnych 6,4, w Ropczycach 5,9 i w Przeworsku 5,8. 


\section{Zasoby mieszkaniowe ośrodków miejskich Podkarpacia}

W 2015 roku wielkość zasobów mieszkaniowych głównych ośrodków miejskich województwa podkarpackiego, tj. Rzeszowa, Przemyśla, Krosna i Tarnobrzega, wyniosła ponad 133 tys. mieszkań i była porównywalna ze stanem dla pozostałych siedemnastu miast powiatowych regionu, wynoszącym ponad 137 tys. Największy udział w zasobach mieszkaniowych posiadał Rzeszów, gdzie zlokalizowanych było ponad 73,7 tys. jednostek lokalowych stanowiących ponad 55\% ogólnej liczby mieszkań czterech głównych miast regionu. W badanym okresie stolica Podkarpacia odnotowała największy wzrost liczby mieszkań - ponad 35\%, przy średniej dla pozostałych trzech miast na poziomie $7,5 \%$ i tylko $4,5 \%$ dla pozostałych miast powiatowych (tab. 3).

Tabela 3. Liczba mieszkań w miastach Podkarpacia na tle kraju w latach 2005-2015

\begin{tabular}{|c|c|c|c|c|c|c|c|c|}
\hline \multirow[t]{2}{*}{ Wyszczególnienie } & \multicolumn{3}{|c|}{$\begin{array}{c}\text { Liczba mieszkań } \\
\text { w latach }\end{array}$} & \multirow[t]{2}{*}{$\begin{array}{l}\text { Dynamika } \\
2005=100\end{array}$} & \multicolumn{3}{|c|}{$\begin{array}{c}\text { Średnia liczba } \\
\text { mieszkań na tysiąc } \\
\text { mieszkańców }\end{array}$} & \multirow[t]{2}{*}{$\begin{array}{c}\text { Przy- } \\
\text { rost }+/- \\
\mathbf{2 0 0 5}=\mathbf{1 0 0}\end{array}$} \\
\hline & 2005 & 2010 & 2015 & & 2005 & 2010 & 2015 & \\
\hline \multicolumn{9}{|l|}{ Miasta powiatowe: } \\
\hline Rzeszów & 54546 & 65657 & 73740 & 135,2 & 344,1 & 366,4 & 396,7 & 52,6 \\
\hline Przemyśl & 23195 & 24303 & 24726 & 106,6 & 346,7 & 373,3 & 394,2 & 47,5 \\
\hline Krosno & 15892 & 16600 & 17475 & 110,0 & 332,4 & 349,4 & 373,6 & 41,2 \\
\hline Tarnobrzeg & 16350 & 16897 & 17404 & 106,4 & 326,2 & 345,6 & 364,0 & 37,8 \\
\hline $\begin{array}{l}\text { Pozostałe miasta } \\
\text { powiatowe }\end{array}$ & 131633 & 134351 & 137618 & 104,5 & 292,2 & 297,2 & 312,9 & 20,8 \\
\hline
\end{tabular}

Źródło: obliczenia własne na podstawie danych BDL GUS

Dynamiczny wzrost zasobów mieszkaniowych w analizowanym okresie przełożył się na wzrost wskaźnika określającego liczbę mieszkań przypadającą na tysiąc mieszkańców. Dla głównych ośrodków miejskich badanego regionu i samego Rzeszowa w 2015 roku średni wskaźnik wynosił odpowiednio 382,1 i 396,7, co stanowiło wzrost w porównaniu do roku 2005 odpowiednio o ponad 45 i 52 mieszkania. Uwzględniając fakt, że średni wskaźnik dla Polski wynosi 363, a dla krajów UE 486,5 mieszkania w przeliczeniu na tysiąc obywateli, w przypadku Rzeszowa jego wartość była wyższa o ponad 9\% w stosunku do średniej dla kraju i o ponad $18 \%$ niższa w stosunku do średniej dla krajów UE. Jednak poziom wskaźnika bliski 400 mieszkaniom/tys. mieszkańców zbliża stolicę Podkarpacia do grupy krajów UE ze średnimi zasobami mieszkaniowymi. Natomiast w odniesieniu do pozostałych miast powiatowych wskaźnik ten w latach 2005-2010 nie osiągał 300 mieszkań/tys. mieszkańców. I mimo że na koniec 2015 roku przekro- 
czył wartość 312, to nie spowodował poprawy sytuacji, gdyż dystans, jaki dzielił miasta powiatowe od czterech głównych ośrodków miejskich, w dalszym ciągu się zwiększał.

Wzrost zasobów mieszkaniowych w badanych ośrodkach miejskich Podkarpacia jest wynikiem poprawy sytuacji mieszkaniowej związanej z budową nowych mieszkań, których dostarczycielem jest pierwotny rynek mieszkaniowy reprezentowany przede wszystkim przez firmy deweloperskie. Jego duże znaczenie w głównych miastach Podkarpacia, zwłaszcza w stolicy województwa, jest skutkiem w dalszym ciągu niskiego nasycenia zasobami mieszkaniowymi. W budowaniu nowych mieszkań niezaprzeczalnym liderem jest Rzeszów, gdzie w 2015 roku oddano do użytkowania 2392 mieszkania, co stanowi rekordowy wynik ${ }^{6}$. W porównaniu do poprzedniego roku, gdy oddano do użytku 1649 mieszkań, nastąpił wzrost o ponad 30\%. Z kolei w 2013 oddano 1346 mieszkań, a więc prawie połowę mniej, w 2012 roku 1576 mieszkań, podobnie w 2011 - 1565. Natomiast w 2010 roku było ponad 2,5 raza mniej wybudowanych mieszkań - tylko 937. Warta zauważenia jest również bardzo wysoka liczba mieszkań - 2435, których budowę rozpoczęto w 2015 roku, z czego aż 1543 to mieszkania przeznaczone na sprzedaż i wynajem?7. Wielkości te świadczą nie tylko o dużej aktywności deweloperów na rynku rzeszowskim i powstawaniu wielu nowych inwestycji mieszkaniowych w tym mieście, ale przede wszystkim o wzrastającej konkurencyjności stolicy Podkarpacia, gdyż przyrost zasobów mieszkaniowych zasadniczo przekłada się na większe znaczenie ekonomiczne ${ }^{8}$, a co za tym idzie - poprawę konkurencyjności regionu w skali kraju i UE9.

Ponadto warto zaznaczyć, że wśród nowych mieszkań oddawanych do użytkowania $w$ badanych ośrodkach miejskich dominowały te przeznaczone na sprzedaż i wynajem (blisko 42\%) oraz indywidualne (ponad 37\%) (tab. 4). W poszczególnych miastach w latach 2010-2015 zauważalne było duże zróżnicowanie struktury własnościowej oddawanych do użytkowania mieszkań. I tak, w Rzeszowie i Krośnie największy udział stanowiły te przeznaczone na sprzedaż i wynajem, natomiast w Tarnobrzegu i Przemyślu indywidualne. Budownictwo indywidualne jednorodzinne, realizowane zazwyczaj systemem gospodarczym, dominowało również w pozostałych miastach powiatowych.

6 Na koniec 2015 roku w Rzeszowie, podobnie jak w kraju, odnotowano rekordowo najwyższą od 2008 roku sprzedaż nowych mieszkań - zob. dane BDL GUS.

7 Dane BDL GUS.

8 Wartość majątku nieruchomości mieszkaniowych szacowana jest na koniec 2015 roku na około 3,1 bln zł, a nieruchomości komercyjnych na około 0,2 bln zł - zob. Raport o sytuacji na rynku nieruchomości..., 2016: 11.

9 W rankingu European Smart Cities 2014, przygotowanym przez Vienna University of Technology, wśród 77 najbardziej docenianych inteligentnych miast Rzeszów zajął 55. pozycję - tuż przed Szczecinem - zob. www.smart-cities.eu [dostęp: 25.02.2017]. 
Niezależnie jednak od wielkości ośrodka w badanych latach nadal obserwowano ograniczenie działalności spółdzielni mieszkaniowych w produkcji nowych mieszkań. Rzeszów - jako jedyny ośrodek miejski regionu, ale również nieliczny wśród miast wojewódzkich Polski - w latach 2010-2015 odnotował ponad 22-procentowy udział budownictwa spółdzielczego w nowo oddawanych inwestycjach mieszkaniowych.

Według prawa władze publiczne prowadzą politykę sprzyjająca zaspokajaniu potrzeb mieszkaniowych obywateli. Rozwinięciem tego przepisu jest artykuł 7 ustępy 1 i 2 ustawy o samorządzie terytorialnym ${ }^{10}$. Samorządy nie mają jednak wystarczających zasobów, wsparcia ani też motywacji, żeby powiększać zasoby komunalne. Wśród czterech głównych ośrodków miejskich Podkarpacia najwyższy udział oddanych mieszkań komunalnych odnotowały Tarnobrzeg (w 2013 roku 8 i w 2015 roku 36) i Przemyśl (w 2010 roku 26). Nowe mieszkania spółdzielcze w liczbie ponad 2 tys. oddano w ostatnich pięciu latach w Rzeszowie, mały odsetek stanowiły nowe mieszkania społeczno-czynszowe, komunalne i zakładowe.

Wśród wskaźników charakteryzujących jakościową stronę zasobów mieszkaniowych badanego regionu w analizowanym okresie 2005-2015 na uwagę zasługują: wzrastająca liczba mieszkań na tysiąc osób i przeciętna powierzchnia użytkowa mieszkania na osobę oraz malejąca przeciętna liczba osób przypadająca na jedno mieszkanie (tab. 5).

Szczegółowe dane pokazały, że największe mieszkania, tj. o powierzchni ponad $80 \mathrm{~m}^{2}$, znajdowały się w 5 spośród 17 miast powiatowych: Łańcucie, Strzyżowie, Kolbuszowej, Nisku i Ropczycach, czyli bliżej położonych względem Rzeszowa - za wyjątkiem Niska (do $30 \mathrm{~km}$ ).

Dobre warunki mieszkaniowe mają kluczowe znaczenie dla atrakcyjności miasta i komfortu życia. W badanych miastach przeciętna powierzchnia użytkowa mieszkania na osobę kształtowała się od 21,2 $\mathrm{m}^{2}$ w Stalowej Woli do 27,6 Łańcucie $^{11}$. Dodatkowo w miastach województwa podkarpackiego odnotowano mieszkania o największej przeciętnej liczbie izb $(3,85)$, przy najmniejszej odnotowanej dla województwa łódzkiego $(3,35)$ i mazowieckiego $(3,42)$.

10 Ustawa z dnia 8 marca 1990 r. o samorządzie terytorialnych (Dz.U. z 2017 r., poz. 1875).

11 Na przykład w Rumunii w przypadku ponad 900 tys. ludzi powierzchnia mieszkania na osobę mieści się w przedziale 3-3,5 m² , co odpowiada powierzchni łóżka i połowy stołu - zob. dane ze spisu powszechnego z 2002 r., w: Housing and Extreme Poverty..., 2006. 


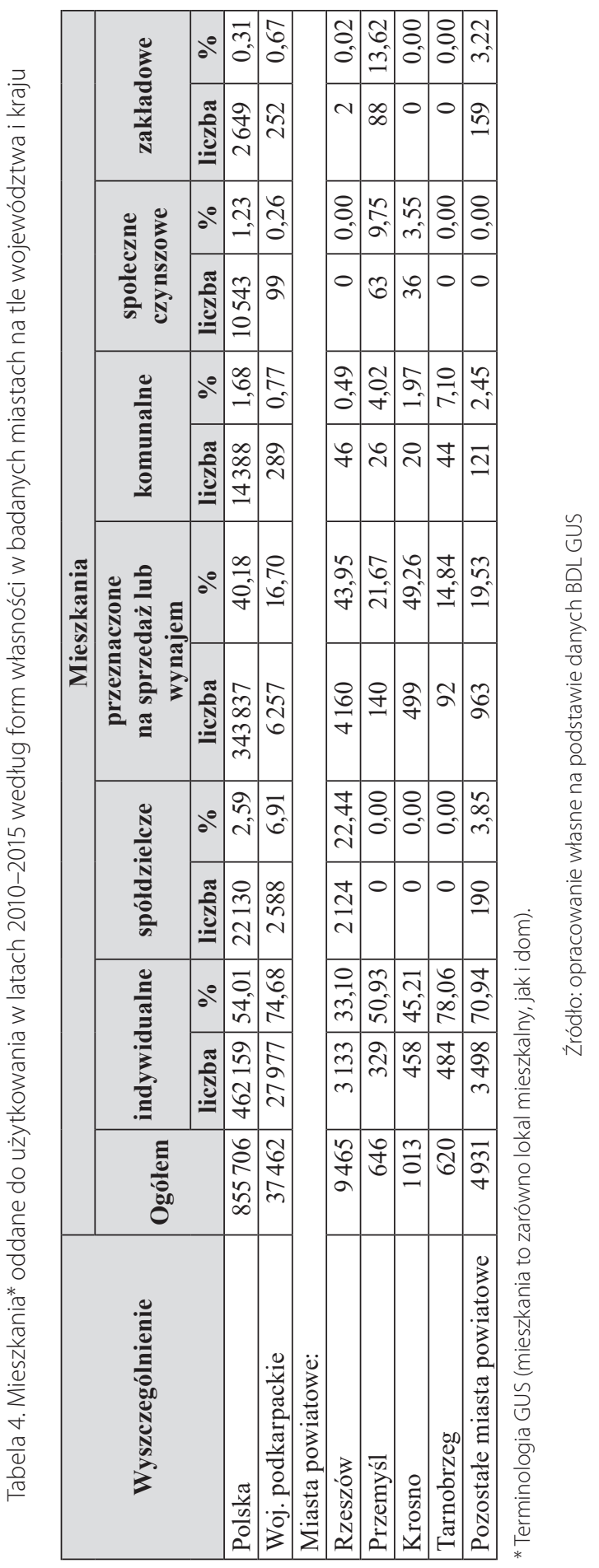




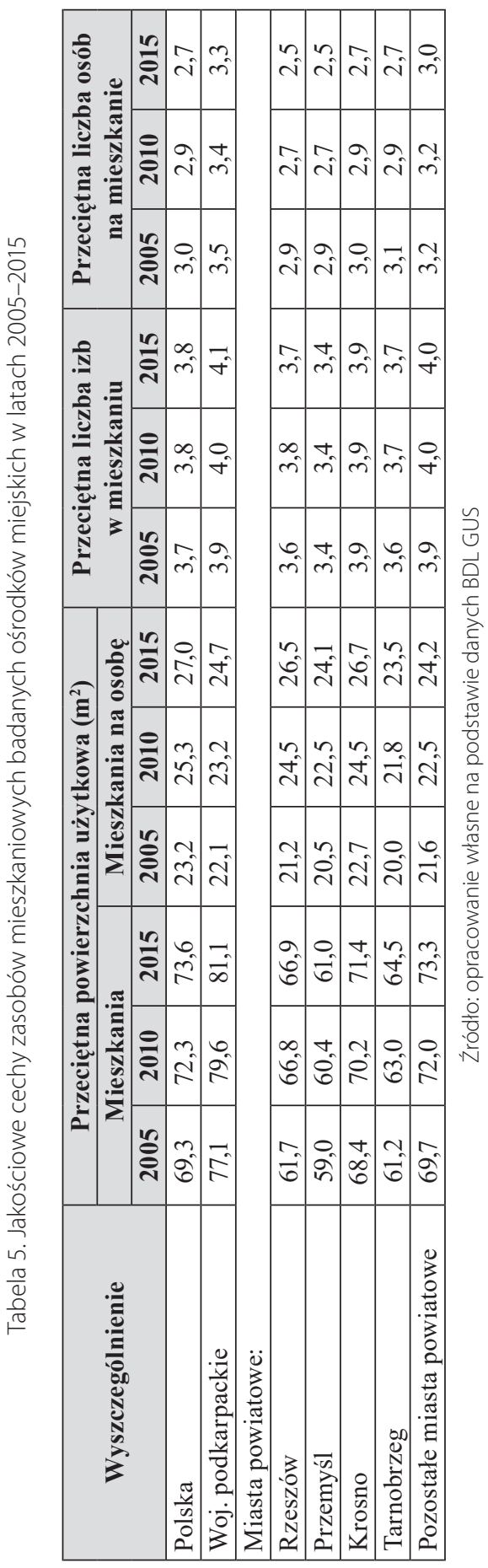




\section{Podsumowanie}

Gospodarka mieszkaniowa regionu przyczynia się do powstawania silnych powiązań z wieloma innymi dziedzinami życia gospodarczego. Inwestycje mieszkaniowe polegają na transferowaniu środków pieniężnych w majątek mieszkaniowy, który stanowi czynnik oddziaływania na procesy odtwarzania i powiększania tego majątku, co z kolei przekłada się na ogólny wymiar ekonomiczny. Nie należy również zapominać, że pozytywne zmiany w zasobach mieszkaniowych ośrodków miejskich Podkarpacia w zasadniczy sposób wpływają na warunki życia i możliwości ich poprawy, co decyduje o przemianach demograficznych danego regionu i w sposób zasadniczy podnosi jego konkurencyjność. Tu szczególną rolę pełni największy ośrodek miejski regionu - Rzeszów.

Położony w centralnej części województwa stanowi istotny węzeł komunikacyjny i jako stolica województwa podkarpackiego jest głównym ośrodkiem regionu, pełniącym funkcje administracyjne, szkolnictwa wyższego, naukowo-badawcze i szerokiego zakresu usług edukacyjnych, ochrony zdrowia, kultury i handlu (Obszary funkcjonalne w woj. podkarpackim, 2015: 13). Jednocześnie Rzeszów należy do grona największych w kraju miast, wyróżniających się w ostatnich latach najwyższymi wskaźnikami rozwoju lokalnego, obok takich znaczących ośrodków, jak Warszawa, Kraków i Wrocław (Adamowicz, Janulewicz, 2016: 83).

Napływ nowych mieszkańców przy jednoczesnym osłabieniu mniejszych ośrodków miejskich regionu przekłada się na sukcesywny wzrost potencjału demograficznego. Dotyczy to najczęściej ludzi młodych, znajdujących tu dogodniejsze warunki życia i rozwoju, co łączy się z wyraźnym rozwojem mieszkalnictwa.

W latach 2005-2015 najbardziej zauważalne pozytywne zmiany zasobów mieszkaniowych odnotowano w stolicy Podkarpacia - Rzeszowie. Pozostałe ośrodki miejskie, w tym te, które straciły status siedzib dawnych województw, tj. Przemyśl, Tarnobrzeg i Krosno, oraz pozostałe miasta powiatowe regionu w okresie dekady tylko nieznacznie zwiększyły liczbę mieszkań. Dodatkowo pogłębiające się zjawisko depopulacji miast powiatowych, a w szczególności Przemyśla, Jarosławia, Leska, Jasła, Stalowej Woli, Tarnobrzega oraz Brzozowa, Sanoka i Krosna nie jest dobrym prognostykiem dla przyszłego ich rozwoju. 


\section{Bibliografia}

Adamowicz M., Janulewicz P. (2016), Ocena rozwoju dużych miast w Polsce - wyniki badań wykorzystujacych wzorzec rozwoju Hellwiga, „Studia Regionalne i Lokalne”, nr 2, DOI: $10.7366 / 1509499526404$.

BDL GUS, www.stat.gov.pl [dostęp: 9.03.2017].

Brol R. (red.) (2001), Ekonomika i zarządzanie miastem, Wydawnictwo Akademii Ekonomicznej, Wrocław.

Cesarski M. (1998), Mieszkaniowy majątek trwaty oraz jego rola w badaniach i polityce mieszkaniowej w Polsce, Wydawnictwo SGH, Warszawa.

Gorzelak G. (2008), Miasto jako przedmiot badań ekonomii, [w:] B. Jałowiecki (red.), Miasto jako przedmiot badań naukowych w poczatkach XXI wieku, Wydawnictwo Naukowe Scholar, Warszawa.

Housing and Extreme Poverty. The Roma Communities Case (2006), UAUIM, Bukareszt.

Koncepcja Przestrzennego Zagospodarowania Kraju do 2030 (2011), Załącznik do uchwały nr 239 Rady Ministrów z dnia 13 grudnia 2011 r. (poz. 252).

Korenik S. (2015), Teoretyczne aspekty gospodarki i polityki regionalnej, [w:] N. Derlukiewicz, K. Miszczak (red.), Gospodarka i polityka regionalna. Nowe tendencje, Wydawnictwo Uniwersytetu Ekonomicznego we Wrocławiu, Wrocław.

Krajowa strategia rozwoju regionalnego 2010-2020. Regiony, miasta, obszary wiejskie (2010), MRR, Warszawa.

Męczyński M., Konecka-Szydłowska B., Gadziński J. (2010), Poziom rozwoju społeczno-gospodarczego i klasyfikacja matych miast w Wielkopolsce, Uniwersytet Adama Mickiewicza w Poznaniu, Poznań.

Miasta przyszłości. Wyzwania, wizje, perspektywy (2011), UE, Komisja Europejska, Dyrekcja Generalna ds. Polityki Regionalnej, Bruksela.

Obszary funkcjonalne $w$ woj. podkarpackim (2015), Załącznik do uchwały nr 86/1977/15 Zarządu woj. podkarpackiego z dnia 25.08.2015, Zarząd Woj. Podkarpackiego, PBPP w Rzeszowie, Rzeszów.

Raport o sytuacji na rynku nieruchomości mieszkaniowych i komercyjnych w Polsce w 2015 r. (2016), Departament Stabilności Finansowej, Warszawa.

Sobol A. (2010), Kategorie potrzeb i jakości życia w kontekście lokalnego rozwoju zrównoważonego, [w:] M. Burchard-Dziubińska, A. Rzeńca, Zrównoważony rozwój na poziomie lokalnym i regionalnym. Teoria i praktyka, Wydawnictwo Uniwersytetu Łódzkiego, Łódź.

Ustawa z dnia 8 marca 1990 r. o samorządzie terytorialnych (Dz.U. z 2017 r., poz. 1875).

www.smart-cities.eu [dostęp: 25.02.2017].

\section{Housing Resources of Urban Areas of the Podkarpackie Province as a Competitive Advantage of the Region}

\footnotetext{
Abstract: The analysis of the collected scientific material has proved that housing resources of urban areas in the province of podkarpackie may become a significant factor for development of demographic potential in the migration processes especially among young people. This, in turn, results in competitive advantage of the region within the country and also the EU. The capital city of the region - Rzeszow is an example of a big city which has been increasing its population via migrations from rural areas within the province due to better working and living conditions. Despite existing depopulating cities such as Łódź or Poznań, there are in Poland such cities as Rzeszow or Warsaw which have become a magnet attracting new dwellers. This may be proved by remarkable increase
} 
in sales of new flats in the primary market and rising number of new flats to rent during the last few years. It should be noted that such a situation has been influenced by changes in economic factors, rise in remuneration in particular, decline in unemployment and the Gross Domestic Product greater than before. Demographic factors such as population growth, positive balance of migration and the number of marriages have become additional factors for certain cities and impacted positively on the demand in the housing market. Nevertheless, the noticeable phenomenon of depopulation and aging in communities in some urban areas in the province of podkarpackie does not pose a positive outlook for the future.

Keywords: housing resources, depopulation, competition

JEL: R31

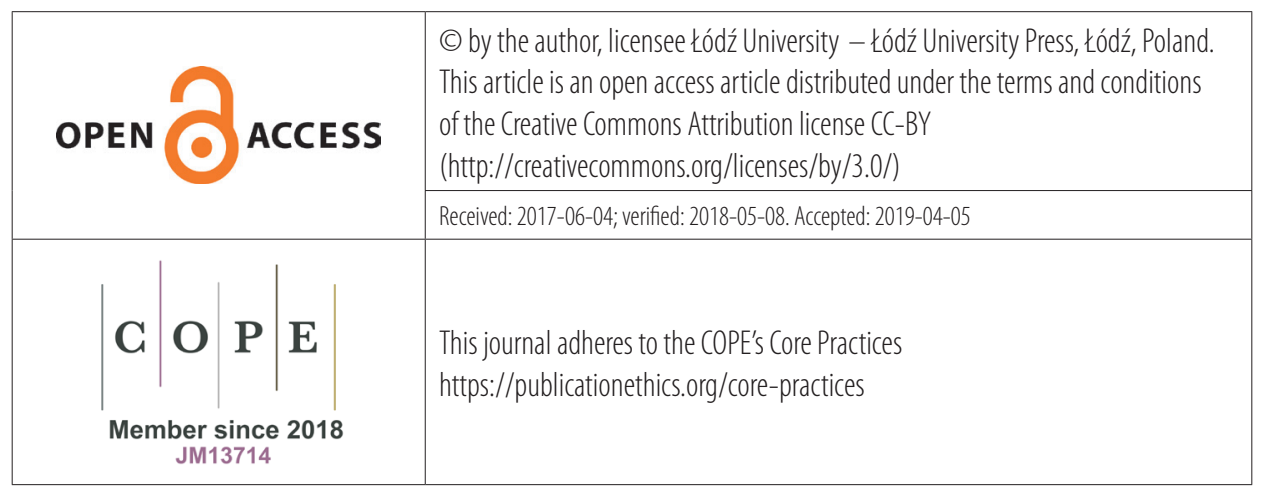

